\title{
Blasts Under 30 Percent of Peripheral Blood White Cells
}

National Cancer Institute

\section{Source}

National Cancer Institute. Blasts Under 30 Percent of Peripheral Blood White Cells. NCI

Thesaurus. Code C143154.

A semi-quantitative microscopic finding indicating that less than 30 percent of the nucleated cells in a peripheral leukocyte sample are immature mononuclear cells. 